\title{
ALLAN AND KARBOWSKI ON THE QUASI-MATHEMATICAL METHOD IN THE EUDEMIAN ETHICS
}

\author{
Allan e Karbowski Acerca do Método Quasi-Matemático na Ética Eudêmia
}

Mariane Farias de Oliveira*

\begin{abstract}
This paper's aim is to consider the I 6 methodological prescription and its relationship with Allan's quasi-mathematical method theory, which aims at bringing Aristotle closer to an Euclidean model. I will also consider Karbowski's objections to Allan and his own thesis, which holds that it is possible to treat book II in accordance with prescription I 6, always going through the vaguest opinions and definitions first only then to the most accurate.
\end{abstract}

Keywords: Ancient Ethics, Aristotle, Method.
Resumo: Nosso objetivo neste artigo é considerar a prescrição metodológica de I 6 e sua relação com a tese do método quasimatemático de Allan, que visa aproximar Aristóteles de um modelo Euclidiano, e as objeções de Karbowski a Allan, bem como sua tese de que é possível tratar o livro II de acordo com a prescrição de I 6, passando sempre das opiniões e definições mais vagas às mais precisas.

Palavras-chave: Ética Antiga, Aristóteles, Método.

\footnotetext{
* Mestranda em Filosofia na Universidade Federal de Santa Maria (UFSM). E-mail: emaryfarias@ gmail.com.
}

\begin{tabular}{|c|c|c|c|c|c|}
\hline intuitio & $\begin{array}{c}\text { ISSN } \\
1983-4012 \\
\end{array}$ & Porto Alegre & Vol.10 - $\mathrm{N}^{\mathrm{o}} .1$ & $\begin{array}{l}\text { Julho } \\
2017 \\
\end{array}$ & p. $68-80$ \\
\hline
\end{tabular}




\section{Introduction}

This paper's goal is to regard the methodological prescription of the Eudemian Ethics ${ }^{1}$ I 6 and its relationship with Allan's quasi-mathematical thesis - which draws Aristotle nearer to Euclid's method while also presenting Karbowski's objections to Allan. Moreover, I will also expound Karbowski's theory, which holds that it is possible to read book II in the light of prescription I 6, always going through the vaguest opinions and definitions first only then to the most precise.

Let us observe here how Aristotle prescribes his method in the sixth chapter of the first book of the Eudemian Ethics:

[1] We must try, by argument, to reach a convincing conclusion on all these questions, using, as testimony [marturios] and by way of example [paradeigmasi], what appears to be the case [phainomenois]. [2] For it would be best if everyone should to turn out to agree with what we are going to say; if not that, that they should all agree in a way and will agree after a change of mind; [3] for each man has something of his own to contribute to the finding of truth, and it is from such [starting points] that we must demonstrate: [4] beginning with things that are correctly said, but not clearly, as we proceed we shall come to express them clearly, with what is more perspicuous at each stage superseding what is customarily expressed in a confused fashion. ${ }^{2}$

The philosopher tries to define in the first sentence how one should precisely guide oneself in order to get to the truth on moral matters or, at least, to clearer concepts. Employing indications is using the endoxa as a starting point, which will be cleared up, in order to have premises or hypotheses used as "models" of the investigation. The second assertion then seems to justify the first, for "it would be best if everyone should to turn out to agree", meaning that it will be easier to establish the endoxa (which are the reputed opinions) as models, making the first reputed opinions survey already seen as a group itself. If that isn't the case, Aristotle goes on: since all men cling to truth - assertion which seems to be the basis of his argument -, one only needs to then prove whatever it is that each one of us can contribute: that is, reputed opinions. In a way, these opinions would already be indications but not models, since they would not have been clarified yet. That is the point when, once more, one has the need to go through the aporiai so as to establish a consistent group and to finally prove what is that something each person has to "contribute to the finding of truth". This should be conforming the initial indications from which one has begun, the nonclarified endoxa, to the established models or paradigms through the enlightenment of the endoxa. One must observe and reach out for patters within the indications as to only then be able to confront them and

\footnotetext{
${ }^{1}$ I will use the abreviation of Ethica Eudemia as EE and Ethica Nicomachea as NE. All the translations of Ethica Eudemia are from the book ARISTOTLE. Eudemian Ethics. Translated and edited by Brad Inwood and Raphael Woolf. Cambridge: Cambridge University Press, 2013.

${ }^{2}$ EE I 6, 1216b26-35.
}

\begin{tabular}{|c|c|c|c|c|c|}
\hline intuitio & $\begin{array}{c}\text { ISSN } \\
1983-4012\end{array}$ & Porto Alegre & Vol.10- No.1 & $\begin{array}{c}\text { Julho } \\
2017\end{array}$ & p. 68-80 \\
\hline
\end{tabular}


to clarify one's opinions. Mansion ${ }^{3}$ proposes an important distinction for the forth assertion: a distinction between the investigation's starting point and knowledge stricto sensu. The first would be the "more understandable to us" (that is, to the observer) whereas the latter would be "more understandable in itself" (that is, due to the nature of the object's knowledgeability). The interpreter highlights an aspect of this distinction in the process of understanding by asserting that "an immediate evidence that imposes itself is more understandable for us, but which doesn't fully satisfy our spirit in such a way that it excited us to proceed investigating" (1979, p. 213-4) Following this interpretation, the endoxa might be taken as to be indications because they are the most understandable for us and, since they are so, they become the starting points of our investigation, which usually goes through the particulars first and then to the universal.

\section{The Endoxa Method}

If book I does in fact confirm itself as a preamble to what will be investigated and if the "endoxa method" is a correct procedure that Aristotle recommends at the beginning of the treatise, one may hold Barnes' thesis, which presents the endoxa as the components of the Eudemian Ethics' method from the beginning until the end of its definitional quest. Let us now take a look at what such procedure consists of.

At the beginning of the akrasia discussion in the Ethica Nicomachea VII 1 (=EE VI 1), Aristotle prescribes the following:

We must, as in all other cases, set the apparent facts before us and, after first discussing the difficulties, go on to prove, if possible, the truth of all common opinions about these affections of the mind, or, failing this, of the greater number and the most authoritative (...). ${ }^{4}$

I will presuppose his analysis on the interchangeability between the phainomena and the endoxa in such a way that one may read "set the apparent facts" as an opinion survey on the matter. It is also advisable to bear in mind Barnes' comment ${ }^{5}$ which states that if phainomena and endoxa refer to the same things in some passages, that still doesn't authorize us to think that they necessarily are synonymous for Aristotle - Barnes owes this qualification to the fact that in other contexts they may refer to different objects, as the phainomena in De Caelo make reference to sensory objects, for instance.

\footnotetext{
${ }^{3}$ MANSION, S. "'Plus connu en soi', 'plus connu pour nous'. Une distinction épistémologique très importante chez Aristote". In: Pensamiento. Vol. 35. Madrid, 1979, p.212.

${ }^{4}$ EN VII 1, 1145b2-6.

${ }^{5}$ BARNES, Jonathan. “Aristóteles e os Métodos da Ética”. In: ZINGANO, M. (org.). Sobre a Ética Nicomaqueia de Aristóteles. SP: São Paulo, Ed. Odysseus, 2010, p.378.
}

\begin{tabular}{|c|c|c|c|c|c|}
\hline intuitio & $\begin{array}{c}\text { ISSN } \\
1983-4012\end{array}$ & Porto Alegre & Vol.10 $-\mathrm{N}^{\circ} .1$ & $\begin{array}{l}\text { Julho } \\
2017\end{array}$ & p. $68-80$ \\
\hline
\end{tabular}


Barnes $^{6}$ distinguishes three important steps established by the following prescription: (1) establishing (tithenai) what seems to be the case, (2) going through (diaporein) the aporias or challenges, (3) proving (deiknynai) the reputed opinions as much as possible. Steps (1) e (2) are practically inseparable, for the doxographical survey itself brings the aporiai forward. According to Barnes, there shall be two moments in which one grasps the reputed opinions: the first would be when one gathers these opinions, which I will here name as "preliminary endoxa" due to the fact that they may present inconsistencies in such a way that they could not all form a group, since a group must be consistent. Secundo, after going through the aporiai, one shall have enlightened endoxa, meaning that they form a group which indicates to the investigator how to proceed next. This preliminary survey of reputed opinions (which dispute the status of truth and are usually in contradiction) will generally take one to a confusing and puzzling path meant to be gone through. With that said, the process of going through aporias mentioned in the passage above becomes clearer and reveals itself as aspiring to preserve the most compatible endoxa as possible, thus forming a consistent group. This will be accomplished through the analyses of the preliminary endoxa and the incompatibilities that show up - for example, in the akrasia discussion in the Ethica Nicomachea, Aristotle points out inconsistencies that derive from Socrates' opinions only to later establish which opinions he can keep or modify.

Now I pass on to step three, (3) "proving the opinions as much as possible". This is the result which came from "going through the aporiai" and reformulating the reputed opinions so as to finally obtaining a consistent group. Barnes ${ }^{7}$ identifies that the notion of "proof" is a kind of problem solving that the initial endoxa survey produced. He stresses that truth is exclusive and exhaustively found in the remain group of reputed opinions. It seems that it is an exhaustive process because the endoxa form a maximally consistent group, meaning that adding any other opinion would make them inconsistent - thus no longer a group. Nonetheless, how can we understand Barnes when he states that truth must be found exclusively through the remaining group of reputed opinions? I am convinced that an Eudemian Ethics passage can be useful to make the procedure's last step comprehensible.

Looking back at the EE I 6 prescription, we can better understand how what was taken as being the investigation's starting point actually works within the "endoxa method". In 1216b28, Aristotle says that "for each man has something of his own to contribute to the finding of truth". As previously exposed, this "thing" everyone can contribute to truth and that needs to be proved is the reputed opinions. In the Ethica Nicomachea VII 1 (EE = VI 1), this is also required. What is proven is not that the truth is the end of the definitional quest, nor that it is a definitive proof given to an argument, but that it is a proof that one

${ }^{6}$ BARNES, Jonathan. "Aristóteles e os Métodos da Ética”. In: ZINGANO, M. (org.). Sobre a Ética Nicomaqueia de Aristóteles. SP: São Paulo, Ed. Odysseus, 2010, p.378.

${ }^{7}$ BARNES, Jonathan. “Aristóteles e os Métodos da Ética”. In: ZINGANO, M. (org.). Sobre a Ética Nicomaqueia de Aristóteles. SP: São Paulo, Ed. Odysseus, 2010, p.378.

\begin{tabular}{|c|c|l|l|l|l|}
\hline intuitio & $\begin{array}{c}\text { ISSN } \\
1983-4012\end{array}$ & Porto Alegre & Vol.10- No.1 & $\begin{array}{l}\text { Julho } \\
2017\end{array}$ & p. 68-80 \\
\hline
\end{tabular}


endoxon or more can build an investigation when they are refined, thus working as a premise. This shows how one should treat the notion of proof and truth as having a very wide-ranging pallet of meaning within Barnes' endoxa method itself, since what is really being proved is the reminisce of the preliminary endoxon. This is precisely what Aristotle prescribed as the EN VII 1 procedure's first step, yet now already in a consistent a properly philosophical group; by properly philosophical I mean that the endoxa can now be properly used for the definitional quest: the endoxa are thus both the investigation's own elements and its starting point.

\section{Book II - Allan's thesis on the "quasi-mathematical" method}

After having endorsed that the procedure in I 6 is based on the refinement and the conformity of the endoxa, which serves as the Eudemian Ethics' prescription throughout, which this paper's hypothesis, one begins to read book II with an odd impression.

In II 1, Aristotle first says that what he shall present comes from reputed opinions ("For wisdom, virtue and pleasure are either in the soul or outside it, and it is those in the soul that are more worthy of choice" 1218b35) and by inductions alike ("Let this be assumed; and about excellence, that it is the best disposition, state, or capacity of anything that has some employment or function." 1219a1-20). Nonetheless, the hypotheses introduced throughout the chapter look more like postulations, for they are not previously examined as endoxa should and they aren't introduced as being the opinions of the wise or of the majority. Allan ${ }^{8}$ also notices that in this passage he seems to use an Euclidean method in which "references assumptions or vague initial definitions". Allan gives away examples that corroborate to his assertion by briefly rebuilding Aristotle's definitional investigation on eudaimonia - going through areté (hypothesis 2, 1218b37) and ergon's definitions first -, even after it had already been identified as being the highest of goods achievable to men in book I. Allan only presents what he believes to be the hypotheses and their consequence for the final definition of eudaimonia: (II 1, 1219a40): practicing complete virtue in a complete human life.

Hypothesis 1a. Goods are two kinds, external goods and those of the soul. 1b. The latter are more desirable than the former. (Based on exoteric reasoning).

2a. Excellence has a meaning where, and only where, its subject has a function or use. 2b. By excellence is meant: disposition ideally adapted to the performance of a function.

3a. Let the better function be that which belongs to the better disposition; $3 \mathrm{~b}$. Let it be gratend that, as dispositions stand in relation to one another, so do their functions or uses.

4. Let end be equivalent to function, and let its definition be: highest or ultimate good, for whose sake all else is done.

${ }^{8}$ ALLAN, J. "Quasi-mathematical method in the Eudemian Ethics". In: MANSION. Aristote et les problèmes de méthode, 1980, p. 309.

\begin{tabular}{|c|c|l|l|l|l|}
\hline intuitio & $\begin{array}{c}\text { ISSN } \\
1983-4012\end{array}$ & Porto Alegre & Vol.10 $-\mathrm{N}^{\circ} .1$ & $\begin{array}{l}\text { Julho } \\
2017\end{array}$ & p. 68-80 \\
\hline
\end{tabular}


5. That soul has a function has already been agreed; let it now be assumed that this function is to instil life.

6. Hence (by the proposition secured in [5]), the function of human soulexcellence is good human life: and by the preceding proposition such life is the chief good attainable by man. (ALLAN, 1980, pp.309-10).

According to the Euclidean or deductive method, each proposition gives out reasons or assures the following proposition so that one can deduce by the hypotheses a definition. Allan also identifies the same argumentative pattern throughout book II when defining kûrios (II 6, 1222b21), eph'autōi (II 6, 1223a4), phrohairesis (II 10, 1226b 16-21) and areté etiké (1227b5-10). Before these examples, Allan holds that definitions are taken by following this method and also that at least the second book advances in an Euclidian manner, with one definition securing the next, connected by a deductive method: “(...) the Eudemian version, carrying out its avowed principle of steady advance from the vague to the clear, arrives in order at a series of connected definitions."

Besides shedding an Euclidian strategy upon Aristotle, Allan also finds similarities between the way Aristotle uses terms that introduce hypotheses and definitional derivations, as hupokeisthō and esto ${ }^{10}$, which he presumes were terms of the mathematical context. These similarities are not conclusive though. Karbowski ${ }^{11}$ takes advantage of this non-conclusive fact and asserts that these terms were already broadly used by philosophers of Aristotle's time and before, including himself. Nonetheless, this is not enough to give up on Allan's theory: Aristotle may have well made use of mathematics' technicality and methodological strategy in his works, thus formulating a deductive structure alongside its closest terms: that is, the mathematical terms.

\section{Karbowski's Critique of Allan}

Karbowski does not identify the passage in which Allan does not rebuild differently than I 6 prescribes (thus subsidized by Barnes' thesis on the compatibility of the endoxa). The author rebuilds the same passage that Allan did, exposing that what he had believed to be hypotheses and postulates had actually already came from Aristotle's text itself, in order to show that it was only a definitional derivation of what is more understandable in itself (by its nature) from the more understandable to us, which are closer to what we morally know: ${ }^{12}$

1. Happiness is the best human good and achievable by action.

\footnotetext{
${ }^{9}$ ALLAN, J. "Quasi-mathematical method in the Eudemian Ethics". In: MANSION. Aristote et les problèmes de méthode, 1980, p. 317.

${ }^{10}$ Hupokeisthō: EE 11.11218b37; hupekeito: EE II.11219a10; hupokeimenon: EE II.11219a29; echeto: EE

II.11219a8; estō: EE II.11219a6, a24; legomen: EE II.7 1217a30; theteon: EE II.7 1217a40.

${ }^{11}$ KARBOWSKI, J. Is Aristotle Eudemian Ethics Quasi-matematical? In: Apeiron, v 1, 2014, p.2.

${ }^{12}$ KARBOWSKI, J. Is Aristotle Eudemian Ethics Quasi-matematical? In: Apeiron, v 1, p.3.
}

\begin{tabular}{|c|c|l|l|l|l|}
\hline intuitio & $\begin{array}{c}\text { ISSN } \\
1983-4012\end{array}$ & Porto Alegre & Vol.10 $-\mathrm{N}^{\circ} .1$ & $\begin{array}{l}\text { Julho } \\
2017\end{array}$ & p. 68-80 \\
\hline
\end{tabular}


2. Good/ends in the soul are best among human goods.

3. Therefore, happiness must be a good (the best good) in the soul.

4. Goods in the soul are either states or activities.

5. Activities are better than states, and the best activity is correlated with the best state.

6. Therefore, happiness must be the best activity in the soul, the one correlated with the best state.

7. The best state of the soul is its excellence.

8. Therefore, happiness is the activity of the good, i.e.: excellent, soul. ${ }^{13}$

His reconstruction presents as its first premise a clarification of what is generally taken as being happiness ${ }^{14}$; the second premise takes profit of what is the general opinion, or endoxa; the forth deals with theses that Aristotle regards as irrevocable ${ }^{15}$ - well, Allan could have here said that there is merely a hypothesis and nothing else -; the fifth premise comes from the already mentioned connection between telos and ergon ${ }^{16}$; finally, the seventh premise comes from an induction (épagogé) ${ }^{17}$. One can tell that almost every premise emerges previously in the text and that more refined notions, that were not at present in the text before, are derived from them until a conclusion is made, which is the aspired definition. In this scenario it is very unlikely that one can take Aristotle's argument as a rebuilt hypotheses aspiring an Euclidian kind of deduction.

There is yet another objection to make: Karbowski presents another argumentative structure as a contrast to the derivation of happiness presented by Allan, aspiring to show that EE II has other argumentative strategies. The author presents a different version of EE II, which in the light of EE I 6, reveals that Aristotle goes through the what is vague and "more understandable for us" to the more precise and "more understandable in itself" when Aristotle derives a clear definition of virtue through an unclear definition of virtue. Let's now take a look at how the author rebuilds the passage on the virtue of character $^{18}$ :

1. Virtue is a state that enables one to perform the best actions and the best orients one to what is best.

2. What is best and more excellent in a given domain is what accords with correct reasoning about that domain.

\footnotetext{
${ }^{13}$ KARBOWSKI, J. Is Aristotle Eudemian Ethics Quasi-matematical? In: Apeiron, v 1, p.3.

${ }^{14}$ EE I.7-8.

${ }^{15}$ EE II 1 1218b6-7.

${ }^{16}$ EE II $11219^{\mathrm{a}} 6-11$.

${ }^{17}$ EE II $11218 b 37-1219^{a} 5$.

${ }^{18} \mathrm{EE}$ II 5, 1222a6-12. Virtue is set down (hupokeitm) to be the sort of state that enables people to perform the best actions and which best orients them towards what is best; and the best and most excellent is what accords with correct reasoning. And this is the mean relative to us between excess and deficiency. It is necessary, then, that virtue of character in each case in a mean point and has to do with certain means in pleasures and pains and in pleasant and painfu1 things. (EE 11.5 1222a6-U, tr. Inwood and Woolf).
}

\begin{tabular}{|c|c|c|c|c|c|}
\hline intuitio & $\begin{array}{c}\text { ISSN } \\
1983-4012\end{array}$ & Porto Alegre & Vol.10 $-\mathrm{N}^{\circ} .1$ & $\begin{array}{l}\text { Julho } \\
2017\end{array}$ & p. $68-80$ \\
\hline
\end{tabular}


3. Correct reasoning about any domain seeks (and hits) the mean relative to us between excess and deficiency in the relevant domain.

4. Virtue of character is concerned with pleasures and pain.

5. Therefore, virtue of character is a mean state and is concerned with the mean (relative to us) to pleasures and pains.

Karbowski holds and presents these methodological steps, being all of them relevant to the I 6 prescription and containing premises (except the second) which can be found in previous discussions in the text. Aristotle introduces the first premise induced by given examples ${ }^{19}$. Then, the second premise isn't a reputed opinion nor is it derived from the first premise, so being simply introduced and then secured by the third premise, which appeals "as much to the induction as to the rational argument" 20 . The forth premise is established by appealing to the soul's multiplicity and their virtues (cf. EE II.4 1221b271222 5). Karbowski's point is to show that, contrary to what Allan suggests, premises are the result of previous discussions that are not actually inserted in his argument. It only involves introduced hypotheses to Allan, nothing more. When looking to Karbowski's view, though, one notices that they are part of the discussion and are introduced from the most vague to the clearer thoughts of the public to only then obtain a definition that is enlightened and not obvious, respecting the I 6 prescription.

\section{Final considerations: rebuilding Allan's thesis}

Even though he doesn't really identify the use of mathematical elements in Aristotle's EE, Karbowski admits that it was deliberately used and was acknowledged by Aristotle. The author brings forth an example from the EE (IV) or EN (V):

The just then is a species of the proportionate (proportion being not a property only of the kind of number which consists of abstract units, but of number in general). For proportion is equality of ratios, and involves four terms at least (that discrete proportion involves four terms is plain, but so does continuous proportion, for it uses one term as two and mentions it twice; e.g.: 'as the line $\mathrm{A}$ is to the line $\mathrm{B}$, so will $\mathrm{C}$ to $\mathrm{D}$, and therefore, alternando, as $\mathrm{A}$ is to $\mathrm{C}, \mathrm{B}$ will be to $\mathrm{D}$. Therefore, also the whole is in the same ratio to the whole; and the distribution pairs them in this way, and if they are so combined, pairs them justly. The conjuction then of the term $A$ with $C$ and of $B$ with $D$ is what is just in distribution, and this species of just is intermediate, and just is what violates proportion; for the proportional is intermediate, and the just is proportionate. (Mathematicians call this kind of proportion geometrical; for it is in geometrical proportion that it follows that the whole is to the whole as either part is to the

${ }^{19}$ EE II.1, 1220²9-34.

${ }^{20}$ KARBOWSKI, J. Is Aristotle Eudemian Ethics Quasi-matematical? In: Apeiron, v 1, p.4; EE II.3 1220b30-6.

\begin{tabular}{|c|c|c|c|c|c|}
\hline intuitio & $\begin{array}{c}\text { ISSN } \\
1983-4012\end{array}$ & Porto Alegre & Vol.10 $-\mathrm{N}^{\mathrm{o}} .1$ & $\begin{array}{l}\text { Julho } \\
2017\end{array}$ & p. $68-80$ \\
\hline
\end{tabular}


corresponding part.) This proportion is not continuous; for we cannot get a single term standing for a person and a thing. ${ }^{21}$

This passage is one of the hardest to understand and I find myself limited to say that it's about distributive justice. In short, the idea is that a just distribution of goods is proportional to each person's merits. Karbowski points out three of the passage's mathematical aspects on ethics: (1) Aristotle deliberately holds that the extension of the concept of proportion (analogy) within ethic matters: this means that it is applied in situations that go beyond the dominium of abstract objects and numbers (including concrete magnitudes and political goods). (2) In 1131b6-7 Aristotle uses the term "alternando" as having the following meaning: four proportional magnitudes ( $\mathrm{A}$ is to $\mathrm{B}$ what $\mathrm{C}$ is to $\mathrm{D}$ ) are also alternately proportional. (3) Aristotle explicitly refers to mathematicians in 1131b12-3 and even uses the term "geometrical", which was thought as a mathematical one, to make reference to the proportion in question $^{22}$.

Karbowski's conclusion is that, though Allan isn't right to be certain that Aristotle uses consciously "a mathematical pattern of deduction" in the EE, the Stagerite certainly was aware of mathematical patterns in other contexts. Karbowski suggests that what we can learn by the passages in which Aristotle uses mathematical terms is properly that he uses an analytic method, and not a deductive one, which is used to discover the elements involved in a proof. This analysis ${ }^{23}$ can be described as the method which begins with someone trying to find (to zetoumenon) in a certain time $\left(\mathrm{t}_{1}\right)$; having this established in a $\left(t_{2}\right)$, it is added to the investigation while someone looks back on what was known in $\left(t_{1}\right)$ and that can occasionally be derived.

Nonetheless, there is little textual evidence to corroborate to what Karbowski aspires, as he himself admits. Reconsidering the quasi-mathematical method essentially consists on the fact that it would be more correct that Allan should have claimed that its arguments in fact resemble mathematical proofs, instead of asserting that the Eudemian Ethics was deliberately molded by the use of mathematical expressions and its postulates. ${ }^{24}$ To do so, Karbowski presents several contexts in which postulates are used, showing that there was a general use of the term in other areas such as medical science, rhetoric, politics, etc. Having that said, one would have to prove that the application of the postulates in the EE is similar to what happens in mathematics in order to state that the EE method is quasi-mathematical. This task is an unsuccessful one since the Euclidian method and Aristotle use postulates in opposite directions: Euclid postulates definitions to build up additional premises, the latter uses preliminary premises (notunderstandable in themselves and more familiar to us) to conclude substantial definitions (understandable

${ }^{21} \mathrm{EN}$ V.3 =EE IV.3 1131a29-b15.

${ }^{22}$ Cf. KARBOWSKI, J. Is Aristotle Eudemian Ethics Quasi-matematical? In: Apeiron, v 1, p.10.

${ }^{23}$ KARBOWSKI, J. Is Aristotle Eudemian Ethics Quasi-matematical? In: Apeiron, v 1, p.8.

${ }^{24}$ KARBOWSKI, J. Is Aristotle Eudemian Ethics Quasi-matematical? In: Apeiron, v 1, p.11.

\begin{tabular}{|c|c|c|c|c|c|}
\hline intuitio & $\begin{array}{c}\text { ISSN } \\
1983-4012\end{array}$ & Porto Alegre & Vol.10 $-\mathrm{N}^{\circ} .1$ & $\begin{array}{l}\text { Julho } \\
2017\end{array}$ & p. $68-80$ \\
\hline
\end{tabular}


in themselves).

In order to conclude, I shan't try to restrain the use of the quasi-mathematical term in the Eudemian Ethics, but only try to show that Allan's interpretation looks only towards one direction and is thus liable to not address important aspects of the method, as the I 6 prescription and the idea of passing from the vaguest to the most precise when dealing with definitions. Aristotle uses postulates, but one must keep in mind that they were broadly used as archai or logos in Aristotle's historical context and that one should so delimitate its use. Karbowski holds that this use was associated to the necessity of dissociating postulates from first principles of moral's dominium, apart from following the criteria of the I 6 prescription.

By following the prescription's criteria, Karbowski refers to the continuity of the I 6 passage that was not here quoted, which consists on deepening the previous prescriptions:

For that way of proceeding is the philosopher's, in every discipline,; but great care is needed here. For, it appears to be the mark of the philosopher never to speak in an unconsidered fashion, but always with reason, there are some that go undetected when they produce arguments that are foreign to the inquiry and idle. (They do this sometimes because of ignorance, sometimes because of charlatans.) By such arguments are caught even by those who are experienced and of practical ability at the hands of men who neither have or are capable of architectonic or practical thought. This happens to them through lack of training; for it is a lack of training to be unable to distinguish, in regard to each subject, between those arguments which are appropriate to it and those which are foreign. It is also a good thing to appraise separately the account of the reason and what is being demonstrated, first because of what has just been said, that we should not in all cases pay attention to what emerges from arguments but often rather to what appears to be the case (as things are, whenever they cannot solve a problem, they are forced to accept what has been said), and secondly because what seems to have been demonstrated by argument is true, but not for the reason that the argument claims. ${ }^{25}$

Karbowski briefly suggests that we all follow this hypothesis, finding conditions that justify Aristotle's use of postulates. First, the properly philosophical argument must be appropriate (oikeion) for its goal $^{26}$; maintain the causal principals separate from the derived facts that they establish ${ }^{27}$; be in accordance to how things appear to us (phainomenois) ${ }^{28}$; have valid arguments ${ }^{29}$; have true premises ${ }^{30}$. Karbowski argues that Aristotle's chief motivation in his arguments is to follow these criteria, that, on the other hand, lead him to using postulates. The challenge remains to understand how these criteria interrelate themselves with the postulates of book II. Having true premises and being a valid arguments

\footnotetext{
${ }^{25}$ EE I 6, 1216b40-1217a17.

${ }^{26}$ EE I 6, 1216b40-1217a10.

${ }^{27}$ EE I 6, 1210a10-1.

${ }^{28}$ EE I 6, 1217a12-4.

${ }^{29}$ EE I 6, 1217a14-6.

${ }^{30}$ EE I 6, 1217a16-7.
}

\begin{tabular}{|c|c|c|c|c|c|}
\hline intuitio & $\begin{array}{c}\text { ISSN } \\
1983-4012\end{array}$ & Porto Alegre & Vol.10 $-\mathrm{N}^{\mathrm{o}} .1$ & $\begin{array}{l}\text { Julho } \\
2017\end{array}$ & p. $68-80$ \\
\hline
\end{tabular}


can be more easily understood as starting the need of using postulates, but how could we then know what analyzing principles separately from their causes is? What about the argument being appropriate for the object? Answering the first question, I believe we should think that it relates to Karbowski's argument: Aristotle's concern with the first principles of the moral domain separately from its postulates. The same kind of separation is what's at stake here. Answering the second, I cannot see a necessary connection with the postulate-use, but only that a postulate could in this case regulate its object beforehand so that it isn't too far off from the field of analysis.

Given the theses and passages analyzed, we can conclude, according to Karbowski's criticisms of Allan's thesis, that Eudemian Ethics does not seem to follow the Euclidian method, for Aristotle's method, although somewhat similar, follows opposite directions as far as which does not postulate its definitions, but part of what is most familiar to us to arrive at more refined premises and their conclusions. Moreover, neither is the method "quasi-mathematical" in the sense that Allan attributes to it: it can only be said quasi-mathematical insofar as the arguments may resemble mathematical proofs, but in relation to the terms employed. These terms which Allan judges to be unique to the mathematics of the time, but which Karbowski shows are jargon used very freely in various areas of knowledge. Thus, it is only in a very vague sense in which the Eudemian Ethics can be said to be quasi-mathematical, although it does retain similarities with mathematics through its proofs. But this is not enough to say that the method prescribed in I 6 is discrepant of the definitional process of book II. Thus, we must conclude that Allan's thesis draws attention to interesting aspects of the second book, but that it is not consistent in his conclusion to hold that Aristotle is following a method different from what was presented in the prescription of I 6.

\begin{tabular}{|c|c|l|l|l|l|}
\hline intuitio & $\begin{array}{c}\text { ISSN } \\
1983-4012\end{array}$ & Porto Alegre & Vol.10 $-\mathrm{N}^{\circ} .1$ & $\begin{array}{l}\text { Julho } \\
2017\end{array}$ & p. 68-80 \\
\hline
\end{tabular}




\section{Referências}

ALLAN, D.J. "Quasi-mathematical method in the Eudemian Ethics". In: MANSION. Aristote et les problèmes de méthode, 1980, pp. 304-318.

ARISTOTE. Éthique à Eudème. Introduction, text grec, traduction, notes, bibliographie et index par Catherine Dalimier. Paris: Flammarion, 2013.

ARISTOTELIS. Ethica Eudemia. R. R. Walzer, J. M. Mingay. Oxford: Oxford University Press, 1991.

ARISTOTLE. Eudemian Ethics - Books I, II, and VIII. Translated with a commentary by MichaelWoods. Oxford: Clarendon Press, 1996.

ARISTOTLE. Eudemian Ethics. Translated and edited by Brad Inwood and Raphael Woolf. Cambridge: Cambridge University Press, 2013.

ARISTOTLE. The Nicomachean Ethics. Translated by David Ross. Oxford: Oxford University Press, 2009.

KARBOWISK, J. Is Aristotle Eudemian Ethics Quasi-matematical? In: Apeiron, v 1, p.1-19, 2014.

Recebido em: 30/11/2016

Aprovado para a publicação em: 24/05/2017

\begin{tabular}{|l|c|c|c|c|c|}
\hline intuitio & $\begin{array}{c}\text { ISSN } \\
1983-4012\end{array}$ & Porto Alegre & Vol.10- No.1 & $\begin{array}{c}\text { Julho } \\
2017\end{array}$ & p. 68-80 \\
\hline
\end{tabular}

